\title{
The Dynamics Of Poverty, Educational Attainment, And The Children Of The Disadvantaged Entering Medical School [Response To Letter]
}

This article was published in the following Dove Press journal:

Advances in Medical Education and Practice

\author{
Aaron D Baugh' \\ Allison A Vanderbilt ${ }^{2}$ \\ Reginald $\mathrm{F}$ Baugh $^{3}$ \\ 'Pulmonary and Critical Care Medicine, \\ Department of Medicine, University of \\ California San Francisco, San Francisco, \\ CA, USA; ${ }^{2}$ Department of Emergency \\ Medicine, Fulton County Health Center, \\ Wauseon, $\mathrm{OH}$, USA; ${ }^{3}$ Department of \\ Surgery, College of Medicine and Life \\ Sciences, University of Toledo, Toledo, \\ $\mathrm{OH}$, USA
}

\section{Dear Editor}

Improving the representation of trainees from low-income households in medicine is a global challenge. While there are broad commonalities in this effort, every country has hosted particular concerns shaped by their unique history, culture, and social structure. We were therefore gratified by the recent letter to the editor from Dr. von Widekind, ${ }^{1}$ who highlighted such concerns in the United Kingdom with the depth of our review ${ }^{2}$ that did not allow and without first-hand perspective available to our authors.

We firmly believe these exchanges embolden us as educators, expanding our armamentarium. It is our sincere hope that others might likewise share their experiences from their own countries. For us, as much as our trainees, cross-cultural exposure to new perspectives enlightens and enriches our sense of the possible.

\section{Disclosure}

The authors report no conflicts of interest in this communication.

\section{References}

1. von Widekind S. The dynamics of poverty, educational attainment, and the children of the disadvantaged entering medical school [Letter]. Adv Med Educ Pract. 2019;10:813-814. doi:10.2147/AMEP. S228840

2. Baugh AD, Vanderbilt AA, Baugh RF. The dynamics of poverty, educational attainment, and the children of the disadvantaged entering medical school. Adv Med Educ Pract. 2019;10:667-676. doi:10.2147/AMEP.S196840
Correspondence: Reginald F Baugh Department of Surgery, College of Medicine and Life Sciences, University of Toledo, 2120 Dowling Hall MS 1905, 3000 Arlington Avenue, Toledo, $\mathrm{OH} 43623$, USA Tel + l 4193836834

Email reginald.baugh@utoledo.edu 
Dove Medical Press encourages responsible, free and frank academic debate. The content of the Advances in Medical Education and Practice 'letters to the editor' section does not necessarily represent the views of Dove Medical Press, its officers, agents, employees, related entities or the Advances in Medical Education and Practice editors. While all reasonable steps have been taken to confirm the content of each letter, Dove Medical Press accepts no liability in respect of the content of any letter, nor is it responsible for the content and accuracy of any letter to the editor.

Advances in Medical Education and Practice

Dovepress

\section{Publish your work in this journal}

Advances in Medical Education and Practice is an international, peerreviewed, open access journal that aims to present and publish research on Medical Education covering medical, dental, nursing and allied health care professional education. The journal covers undergraduate education, postgraduate training and continuing medical education including emerging trends and innovative models linking education, research, and health care services. The manuscript management system is completely online and includes a very quick and fair peer-review system. Visit http://www.dovepress.com/testimonials.php to read real quotes from published authors. 